\title{
Faktor pembelajaran kewirausahaan dan motivasi berwirausaha dalam meningkatkan niat berwirausaha
}

\author{
K. Hafizhah ${ }^{1}$, H. Mulyadi \& D. H. Utama \\ Universitas Pendidikan Indonesia \\ Khansahafiz23@gmail.com
}

\begin{abstract}
The main goals of this study is to derive the positive effect of entrepreneurial learning on entrepreneurial intentions, the effect of entrepreneurial motivation on entrepreneurial intentions, and the combined influence of entrepreneurial learning and entrepreneurial motivation on entrepreneurial intentions. This study has been performed using a group of students from the Bandung City Vocational egvtechnique used was a questionnaire with a sample size of 107 respondents. The results of this study found that the influence of entrepreneurial learning on entrepreneurial intentions belonged to the strong category, motivational motivation influenced the intention of entrepreneurship included in the strong category, and entrepreneurial learning and entrepreneurial motivation influenced the intention of entrepreneurship, including in the strong category. (In this study it is found, if the picture of entrepreneurial learning was effective, it would increase the intention of student entrepreneurship.) The high motivation of student entrepreneurship will create a high intention of entrepreneurship. In addition, if entrepreneurial learning is effective and coupled with a high motivation for entrepreneurship, the intention of student entrepreneurship will increase.
\end{abstract}

Keywords: motivation for entrepreneurship; intention of entrepreneurship; entrepreneurship learning.

Abstrak: Tujuan penelitian yaitu untuk mengetahui pengaruh pembelajaran kewirausahaan terhadap niat berwirausaha, pengaruh motivasi berwirausaha terhadap niat berwirausaha, serta pengaruh pembelajaran kewirausahaan dan motivasi berwirausaha terhadap niat berwirausaha. Objek yang menjadi unit analisis dalam penelitian ini adalah siswa SMK Negeri Kota Bandung. Jenis penelitian yang digunakan adalah verifikatif dengan metode explanatory survey. Teknik pengumpulan data yang digunakan adalah kuesioner dengan jumlah sampel 107 responden. Hasil penelitian ini menemukan bahwa pengaruh pembelajaran kewirausahaan terhadap niat berwirausaha sebesar 66,6\% termasuk ke dalam kategori kuat, motivasi berwiruasaha berpengaruh terhadap niat berwirausaha sebesar $63,3 \%$ yang termasuk ke dalam kategori kuat, serta pembelajaran kewirausahaan dan motivasi berwirausaha berpengaruh sebesar $71,9 \%$ terhadap niat berwirausaha dan termasuk ke dalam kategori kuat. Dalam penelitian ini ditemukan jika gambaran pembelajaran kewirausahaan efektif, maka akan meningkatkan niat berwirausaha siswa. Tingginya motivasi berwirausaha siswa akan menciptakan niat berwirausaha yang tinggi. Selain itu jika pembelajaran kewirausahaan yang efektif dan dibarengi dengan motivasi berwirausaha yang tinggi, maka niat berwirausaha siswa akan meningkat.

Kata Kunci: motivasi berwirausaha; niat berwirausaha; pembelajaran kewirausahaan.

\section{PENDAHULUAN}

Proses penciptaan usaha baru terungkap dari waktu ke waktu, dan tahap pertama adalah mempunyai niat kewirausahaan (Biraglia \& Kadile, 2016). Niat kewirausahaan seseorang mencerminkan tingkat ketertarikan mereka di awal bisnis. Niat berwirausaha juga bisa tergantung pada faktor eksternal seperti faktor ekonomi yang kurang baik dan sulitnya mencari pekerjaan. Tidak semua orang memiliki niat yang sama dalam menghadapi keadaan eksternal yang sama. Hal ini menunjukkan 
peran penting untuk faktor individu, termasuk kepribadian karakteristik demografi seperti usia, jenis kelamin, pendidikan (De Clercq, Honig, \& Martin, 2011)

Niat kewirausahaan didefinisikan sebagai perasaan positif yang dialami oleh calon pengusaha dalam kegiatan yang berhubungan dengan hal-hal yang berarti untuk identitas diri dari pengusaha (Laaksonen, Ainamo, \& Karjalainen, 2011). Inti dari definisi ini adalah agar kita semangat untuk memikirkan kegiatan kewirausahaan, seperti menjelajahi baru ide-ide pasar, mencari sumber pendiri modal, dan mencari cara membangun dan mengembangkan produk baru, yang dapat mendukung individu untuk menjadi pengusaha. Akademisi dan praktisi setuju bahwa niat merupakan aspek penting dari proses kewirausahaan, dengan implikasi penting bagi motivasi dan energi, ketekunan, dan usaha kerja calon pengusaha (Thorgren \& Wincent, 2015).

Praktisi kewirausahaan dan akademisi setuju bahwa emosi kewirausahaan berperan dalam mempengaruhi kognisi kewirausahaan, perilaku, dan hasil. niat kewirausahaan mengacu pada mempengaruhi, emosi, suasana hati, dan / atau perasaan-individu atau kolektif -bahwa yang mendahului, bersamaan dengan, dan / atau konsekuensi dari proses kewirausahaan, yang berarti pengakuan / pembuatan, evaluasi, reformulasi, dan / atau eksploitasi peluang yang mungkin (Breugst, Domurath, Patzelt, \& Klaukien, 2012). Baru-baru ini, telah ada peningkatan niat dalam pengalaman emosional yang spesifik, gairah kewirausahaan, yang memiliki dampak signifikan pada kewirausahaan perilaku (Davis, Webb, \& Coombs, 2014). Niat berwirausaha penting karena meningkatkan keyakinan pengusaha bahwa pekerjaan mereka adalah bermakna, mengarah ke tingkat yang lebih besar dari ketekunan dalam usaha kegiatan, meningkatkan kreativitas dalam pemecahan masalah, dan meningkatkan kepemilikan pengalaman berkaitan dengan keberhasilan usaha dan kegagalan (Mason-Jones D.R., 1999). Niat kewirausahaan meningkatkan pameran kepemimpinan transformasional dan emosional menampilkan, yang dapat mempengaruhi gairah karyawan dan keterlibatan dan, secara umum, meningkatkan niat investor dalam perusahaan (Mitteness,Sudek, dan Cardon, 2012). Niat berwirausaha di Indonesia masih sangat rendah, seperti di lansir dari www.swa.co.id jumlah wirausahawan Indonesia pada tahun 2015 persentasenya hanya $1,64 \%$ dari total jumlah penduduk sekitar 250 juta, jauh lebih kecil dari nilai standar internasional sebesar $2 \%$. Kalau dilihat dari pengusaha yang masih fokus pada inovasi dalam produksinya, angkanya di Indonesia lebih kecil lagi, yakni hanya 0,3\%. "Angka itu jauh tertinggal dari Malaysia sebesar 2,1\%, Korea Selatan 4,1\%, Thailand 4\%, China dan Jepang $10 \%$, dan Amerika Serikat 12\% (swa.co.id).

Dalam rangka memperluas literatur yang ada, studi ini mengkaji interaksi dalam penelitian niat kewirausahaan dan keberhasilan berwirausaha. Niat belajar kewirausahaan mencerminkan kecenderungan orang untuk memperbarui pengetahuan mereka saat ini diatur secara terus menerus, seperti kemampuan kognitif. Niat untuk berwirausaha mengukur sejauh mana orang 'menyukai' untuk bekerja dan memperoleh sukacita dari investasi dalam kegiatan yang berhubungan dengan pekerjaannya. Tidak seperti orientasi bekerja, niat berwirausaha mengukur aspek emosional dari pendekatan orang untuk bekerja. Dapat diartikan bahwa orang-orang yang memiliki niat untuk berwirausaha cenderung terlibat dalam pengolahan pengetahuan yang lebih intensif dan sistematis ketika tuntutan terkait tugasmemerlukannya (Frederickson, 1998; Ho et al, 2011).

Tabel 1. Pengangguran terbuka angkatan kerja periode Tahun 2015-2018

\begin{tabular}{clccccc}
\hline \multirow{2}{*}{ No. } & \multirow{2}{*}{ Pendidikan Tertinggi Yang Ditamatkan } & \multicolumn{5}{c}{ Februari } \\
\cline { 3 - 6 } & & 2014 & 2015 & 2016 & 2017 & 2018 \\
\hline 1 & Tidak/belum pernah sekolah & 134,040 & 124.303 & 94.293 & 92,331 & 42,039 \\
2 & Tidak/belum tamat SD & 610,574 & 603.194 & 557.418 & 546,897 & 446,812 \\
3 & SD & $1,374,822$ & 1.320 .392 & 1.218 .954 & $1,292,234$ & 967,630 \\
4 & SLTP & $1,693,203$ & 1.650 .387 & 1.313 .815 & $1,281,240$ & $1,249,761$
\end{tabular}




\begin{tabular}{|c|c|c|c|c|c|c|}
\hline \multirow{2}{*}{ No. } & \multirow{2}{*}{ Pendidikan Tertinggi Yang Ditamatkan } & \multicolumn{5}{|c|}{ Februari } \\
\hline & & 2014 & 2015 & 2016 & 2017 & 2018 \\
\hline 5 & SLTA Umum/SMU & $1,893,509$ & 1.762 .411 & 1.546 .699 & $1,552,894$ & $1,650,636$ \\
\hline 6 & SLTA Kejuruan/SMK & 847,365 & 1.174 .366 & 1.348 .327 & $1,383,022$ & $1,424,428$ \\
\hline 7 & Akademi/Diploma & 195,258 & 254.312 & 249.362 & 249,705 & 300,845 \\
\hline 8 & Universitas & 398,298 & 565.402 & 695.304 & 606,939 & 789,113 \\
\hline & Total & $7,147,069$ & 7.454 .767 & 7.024 .172 & $7,005,262$ & $6,871,264$ \\
\hline
\end{tabular}

Sumber data : Badan Pusat Statistik 2018

Dilihat dari data di atas, terlihat jumlah pengangguran terdidik lulusan SLTA Kejuruan/SMK cukup tinggi. Tingkat pengangguran di jenjang pendidikan SMK naik karena lulusan SMK didorong untuk menjadi seorang wirausaha. Namun pada kenyataannya, banyak alumni SMK ini yang belum siap mengimplementasikan ilmunya sebagai entrepreneur dan memilih untuk bekerja di perusahaan. Karena mereka belum berani jadi wirausaha, akhirnya menjadi buruh atau karyawan dulu.

Sementara lapangan kerja yang menyerap mereka terbatas. Hal ini bertolak belakang dengan tujuan SMK yang seharusnya mampu mengurangi tingkat pengangguran di Indonesia. Menurut hasil penelitian, banyaknya pengangguran terbuka pun disebabkan oleh rendahnya sikap berwirausaha padahal menjadi seorang wirausaha merupakan salah satu pendukung yang menetukan maju mundurnya perekonomian, karena bidang wirausaha mempunyai kebebasan untuk berkarya dan mandiri (Mulyadi, Razati, \& Ramadhanti, 2013). Keadaan ini bukanlah sebuah pilihan untuk tidak bekerja, tetapi akibat dari semakin sulitnya mendapatkan pekerjaan. Masalah tersebut sebenarnya dapat diperkecil dengan cara menumbuh kembangkan kewirausahaan dan menjadi wirausaha merupakan alternatif pilihan yang tepat (Roy, Akhtar, \& Das, 2017).

Salah satu upaya untuk meningkatkan jumlah wirausaha adalah melalui jalur pendidikan (Mulyadi et al., 2013). Pendidikan kejuruan dinilai sebagai solusi praktis mengurangi jumlah pengangguran (Thahara \& Mulyadi, 2016). Selain itu, pendidikan kejuruan juga dinilai strategis dalam meningkatkan kualitas sumber daya manusia (SDM) Indonesia (Thahara \& Mulyadi, 2016).
Calon lulusan SMK sekarang ini harus memiliki inisiatif membuka lapangan pekerjaan sendiri sehingga tidak akan lagi menambah angka pengangguran yang ada di Indonesia (Roy et al., 2017). Sekolah diharapkan mampu menyiapkan lulusannya untuk berdiri sendiri dengan membuka usaha yang dapat memberikan penghidupan bagi dirinya dan masyarakat sekitarnya. Salah satu caranya dengan mendidik siswa untuk berwirausaha.

Sekolah Menengah Kejuruan Negeri di Bandung terindikasi memiliki jumlah lulusan yang sangat sedikit meneruskan ke bidang wirausaha. Berdasarkan hasil rekapitulasi yang dilakukan sekolah mengenai terlusuran lulusan, siswa yang meneruskan untuk menjadi wirausaha dapat dilihat pada Tabel 2.

Tabel 2. Rekapitulasi lulusan yang berwirausaha di SMK Negeri kota Bandung tahun 2015-2018

\begin{tabular}{|c|c|c|c|c|}
\hline No & Tahun & Jumlah & $\begin{array}{l}\text { Jumlah } \\
\text { Siswa }\end{array}$ & $\begin{array}{l}\text { Persentase } \\
(\%)\end{array}$ \\
\hline 1 & 2015 & 10 & 700 & 1.43 \\
\hline 2 & 2016 & 7 & 657 & 1.07 \\
\hline 3 & 2017 & 12 & 674 & 1.78 \\
\hline 4 & 2018 & 20 & 741 & 2.70 \\
\hline
\end{tabular}

Table 2 menjelaskan mengenai rekapitulasi lulusan siswa di SMK Negeri Bandung yang meneruskan untuk berwirausaha. Tahun 2015 jumlah siswa yang meneruskan untuk berwirausaha sebanyak 10 orang dari jumlah siswa sebanyak 700 siswa atau $1,43 \%$ dari jumlah total siswa yang lulus pada tahun tersebut. Terjadi penurunan yang cukup siginifikan yaitu menjadi 7 siswa dari jumlah siswa 657 siswa atau 1,07\% dari jumlah total siswa yang lulus. Hal tersebut menunjukan bahwa terjadinya penurunan niat berwirausaha siswa di SMK Negeri Bandung. 
Tahun 2017 sampai 2018 terjadi kenaikan yang cukup tinggi menjadi $2,70 \%$ siswa atau 20 siswa dari 741 siswa yang lulus pada tahun 2018. Meskipun terjadi kenaikan yang cukup tinggi, hal tersebut masih jauh dari target yang sekolah buat. Berdasarkan hasil wawancara dengan kepala bagian Hubin SMK Negeri Bandung pada tanggal 21 September 2018 menyatakan bahwa sekolah menargetkan siswa yang berwirausaha setelah lulus sekolah sebesar 25\%-35\% dari jumlah lulusan saat itu. Pihak sekolah telah banyak melakukan tindakan agar jumlah siswa yang berwirausaha setelah lulus meningkat dengan cara seperti mengadakan seminar mengenai kewirausahaan, tetapi masih banyak siswa yang tidak melanjutkan untuk berwirausaha.

Untuk mengetahui kondisi pembelajaran kewirausahaan, motivasi berwirausaha dan niat berwirausaha yang dimiliki para siswa kelas XI di SMK Negeri Bandung sebagai tolak ukur pendukung jumlah siswa dan mengukur harapan produktivitas lulusan SMK Negeri Bandung, telah dilakukan penyebaran angket kepada 35 siswa kelas XI dari setiap jurusan di SMK Negeri Bandung yang sedang belajar mata pelajaran kewirausahaan. Adapun hasil pra penelitian mengenai niat berwirausaha yaitu niat pada para siswa, dapat dilihat pada tabel 1.3 berikut.

Tabel 3. Hasil pra penelitian gambaran niat berwirausaha siswa SMK Negeri kota Bandung

\begin{tabular}{|c|c|c|c|}
\hline \multirow[b]{2}{*}{$\begin{array}{l}\mathrm{N} \\
\mathrm{o}\end{array}$} & \multirow[b]{2}{*}{ Pernyataan } & \multicolumn{2}{|c|}{ Jawaban } \\
\hline & & $\mathrm{Ya}$ & $\begin{array}{l}\text { Tida } \\
\mathrm{k}\end{array}$ \\
\hline 1 & $\begin{array}{l}\text { Saya memiliki keseriusan menciptakan } \\
\text { usaha setelah lulus sekolah }\end{array}$ & $\begin{array}{l}41 . \\
7\end{array}$ & 58.3 \\
\hline 2 & $\begin{array}{l}\text { Saya memiliki tekad yang kuat untuk } \\
\text { belajar mengenai berwirausaha }\end{array}$ & $\begin{array}{l}37 . \\
1\end{array}$ & 62.9 \\
\hline 3 & $\begin{array}{l}\text { Saya selalu tertarik untuk mengikuti } \\
\text { kegiatan-kegiatan yang berhubungan } \\
\text { dengan berwirausaha }\end{array}$ & $\begin{array}{l}37 . \\
1\end{array}$ & 62.9 \\
\hline Total & & $\begin{array}{l}38 \\
6 \\
\end{array}$ & 61,4 \\
\hline
\end{tabular}

Sumber: Hasil pengolahan data tahun 2018

Berdasarkan Tabel 3. menjelaskan gambaran niat berwirausaha siswa kelas XI SMK Negeri kota Bandung. Siswa yang menjawab YA pada sebanyak 38,6\%, hal tersebut menggambarkan bahwa kondisi niat berwirausaha para siswa yang sedang belajar mata pelajaran kewirausahaan masih dianggap rendah. Terlihat sebagian besar siswa memiliki tingkat ketertarikan yang rendah untuk menjalankan bisnis, meskipun telah dibekali pengetahuan dan pengalaman menjalankan bisnis baik sendiri maupun berkelompok untuk mendapatkan pengalaman berbisnis maupun tambahan uang saku atau belajar untuk hidup mandiri secara finansial. Kemudian, niat mahasiswi yang memilih untuk berwirausaha setelah lulus sekolah dinilai rendah karena lebih mengutamakan untuk menjadi pegawai pada suatu instansi atau meneruskan kuliah daripada membuka lapangan kerja sendiri.

Berikut kondisi pembelajaran kewirausahaan siswa SMK Negeri kota Bandung, dapat dilihat pada Tabel 4. di bawah ini.

Tabel 4. Hasil pra penelitian gambaran pembelajaran berwirausaha siswa SMK Negeri kota Bandung

\begin{tabular}{|c|c|c|c|}
\hline \multirow[b]{2}{*}{ No } & \multirow[b]{2}{*}{ Pernyataan } & \multicolumn{2}{|c|}{ Tanggapan } \\
\hline & & Ya & $\begin{array}{l}\text { Tida } \\
\mathrm{k}\end{array}$ \\
\hline 1 & $\begin{array}{l}\text { Guru menjelaskan tujuan } \\
\text { pembelajaran kewirausahaan } \\
\text { pada awal pembelajaran }\end{array}$ & $\begin{array}{l}31 . \\
4\end{array}$ & 68.6 \\
\hline 2 & $\begin{array}{l}\text { Saya mampu mengerjakan } \\
\text { tugas kewirausahaan yang } \\
\text { diberikan oleh guru }\end{array}$ & $\begin{array}{l}31 . \\
4\end{array}$ & 68.6 \\
\hline 3 & $\begin{array}{l}\text { Saya dapat dengan mudah } \\
\text { mengerti materi kewirusahaan } \\
\text { yang disampaikan oleh guru } \\
\text { saat pembelajaran di kelas }\end{array}$ & $\begin{array}{l}42 . \\
9\end{array}$ & 57.1 \\
\hline 4 & $\begin{array}{l}\text { Saya paham dengan materi } \\
\text { yang disampaikan oleh guru } \\
\text { kewirausahaan di kelas }\end{array}$ & $\begin{array}{l}37 . \\
1\end{array}$ & 62.9 \\
\hline 5 & $\begin{array}{l}\text { Guru menyampaikan materi } \\
\text { kewirausahaan dengan } \\
\text { cara/metode yang berebeda- } \\
\text { beda }\end{array}$ & $\begin{array}{l}37 . \\
1\end{array}$ & 62.9 \\
\hline 6 & $\begin{array}{l}\text { Guru menggunakan } \\
\text { menggunakan media } \\
\text { pembelajaran saat } \\
\text { menyampaikan materi } \\
\text { kewirausahaan }\end{array}$ & $\begin{array}{l}31 . \\
4\end{array}$ & 68.6 \\
\hline 7 & $\begin{array}{l}\text { Guru selalu memberikan soal- } \\
\text { soal singkat (kuis atau } \\
\text { ulangan) diakhir pembelajaran } \\
\text { kewirausahaan }\end{array}$ & $\begin{array}{l}48 . \\
6\end{array}$ & 51.4 \\
\hline Total & & $\begin{array}{l}37 \\
1\end{array}$ & 62,9 \\
\hline
\end{tabular}

Sumber: Hasil pengolahan data tahun 2018 
Berdasarkan Tabel 4. menjelaskan gambaran pembelajaran siswa SMK Negeri kota Bandung. Siswa yang menjawab YA pada sebanyak $37,2 \%$, hal tersebut menggambarkan bahwa pembelajaran kewirausahaan siswa kelas XI sebagian besar masih dianggap lemah dalam proses belajar menjadi seorang wirausaha. Hal ini berkaitan dengan niat berwirausaha yang juga rendah dimana kebanyakan siswa tidak memiliki bisnis yang sedang dijalankan, serta keinginan yang rendah untuk menjadi wirausaha setelah lulus sekolah. Adapun pernyataan-pernyataan pembalajaran kewirausahaan yang dijadikan penilaian pra penelitian pada siswa SMK Negeri kota Bandung berkaitan dengan dimensi dari teori pembelajaran kewirausahaan yaitu tujuan pembelajaran, peserta didik, tenaga kependidikan, perancangan pengajaran kewirausahaan, metode pembelajaran, media pengajaran, dan evaluasi pengajaran.

Motivasi berwirausaha menurut Sukmaningrum \& Rahardjo (2017) menjadi salah satu faktor dalam mendukung meningkatnya niat berwirausaha, Tabel 5 menjelaskan kondisi motivasi berwirausaha siswa di SMK Negeri kota Bandung.

Tabel 5. Hasil pra penelitian gambaran motivasi berwirausaha siswa SMK Negeri kota Bandung

\begin{tabular}{|c|c|c|c|}
\hline \multirow{2}{*}{ No } & \multirow{2}{*}{ Pernyataan } & \multicolumn{2}{|c|}{ Jawaban } \\
\hline & & $\mathrm{Ya}$ & Tidak \\
\hline 1 & $\begin{array}{l}\text { Saya memiliki kemauan } \\
\text { untuk menjadi seorang } \\
\text { wirausaha }\end{array}$ & 31.4 & 68.6 \\
\hline 2 & $\begin{array}{l}\text { Saya memiliki semangat } \\
\text { yang tinggi untuk memiliki } \\
\text { usaha sendiri tanpa putus } \\
\text { asa }\end{array}$ & 31.4 & 68.6 \\
\hline 3 & $\begin{array}{l}\text { Saya memiliki keyakinan } \\
\text { usaha yang dijalankan akan } \\
\text { sukses }\end{array}$ & 28.6 & 71.4 \\
\hline 4 & $\begin{array}{l}\text { Saya memiliki keinginan } \\
\text { untuk menjadi seorang } \\
\text { pemimpin dalam sebuah } \\
\text { usaha }\end{array}$ & 34.3 & 65.7 \\
\hline 5 & $\begin{array}{l}\text { Saya memiliki potensi untuk } \\
\text { menciptkan usaha yang } \\
\text { kreatif dan inovatif }\end{array}$ & 37.1 & 62.9 \\
\hline
\end{tabular}

\begin{tabular}{llll}
\hline \multirow{2}{*}{ No } & \multirow{2}{*}{ Pernyataan } & \multicolumn{2}{c}{ Jawaban } \\
\cline { 2 - 4 } & Ya & Tidak \\
\hline 6 & $\begin{array}{l}\text { Saya memiliki cita-cita } \\
\text { untuk menjadi pengusaha }\end{array}$ & 31.4 & 68.6 \\
7 & $\begin{array}{l}\text { sukses } \\
\text { Saya memiliki kemampuan } \\
\text { dalam menciptakan sebuah } \\
8\end{array}$ & 40.0 & 60.0 \\
& $\begin{array}{l}\text { usaha } \\
\text { Saya yakin usaha yang akan } \\
\text { dijalani dapat bersaing } \\
\text { dengan pengusaha lain }\end{array}$ & 34.3 & 65.7 \\
Total & 33,6 & 66,4 \\
\hline
\end{tabular}

Sumber: Hasil pengolahan data tahun 2018

Berdasarkan Tabel 5 menjelaskan gambaran pembelajaran siswa SMK Negeri kota Bandung. Siswa yang menjawab YA pada sebanyak $33,6 \%$, hal tersebut menggambarkan bahwa motivasi berwirausaha siswa kelas XI sebagian besar masih dianggap lemah dalam memiliki motivasi menjadi seorang wirausaha. Hal ini berkaitan dengan niat berwirausaha yang juga rendah di mana kebanyakan siswa tidak memiliki bisnis yang sedang dijalankan, serta keinginan yang rendah untuk menjadi wirausaha setelah lulus sekolah. Adapun pernyataan-pernyataan motivasi berwirausaha yang dijadikan penilaian pra penelitian pada siswa SMK Negeri kota Bandung berkaitan dengan dimensi dari teori motivasi berwirausaha yaitu ) need for achievement, 2) locus of control, 3) vision, 4) desire independence, 5) egoistic passion, 6) drive, 7) goal setting, dan 8) self-efficacy.

Suatu negara akan maju dan stabil perekonomiannya jika penduduk yang menjadi wirausahawan minimal 2\% dari jumlah penduduk. Majunya suatu negara dapat dilihat dari banyaknya wirausahawan di negara tersebut, semakin banyak jumlah wirausahawan semakin besar harapan masyarakat dapat memperoleh pekerjaan sesuai dengan keahlian. Kewirausahaan menjadi solusi terbaik yang di programkan pemerintah. Kewirausahaan menuntut adanya sikap disiplin dan sistematis dalam penerapan inovasi dan kreativitas untuk memecahkan persoalan hidup serta mencapai kehidupan yang lebih baik (Roy et al., 2017).

Pendidikan kewirausahaaan menjadi salah satu faktor yang dapat meningkatkan niat berwirausaha 
siswa. Lestari \& Wijaya (2012) pendidikan kewirausahaan dapat membentuk pola pikir, sikap, dan perilaku pada siswa menjadi seorang wirausahawan (entrepreneur) sejati, sehingga mengarahkan mereka untuk memiliki berwirausaha sebagai pilihan karir. Menurut Alberti, Sciascia, \& Poli (2004) menjelaskan tujuan dari pendidikan kewirusahaan untuk memperoleh pengetahuan yang berhubungan erat dengan kewirausahaan, memperoleh keterampilan dalam menggunakan teknik, analisis situasi usaha, dan menyusun rencana kerja, mengidentifikasi motivasi, potensi, bakat dan keterampilan kewirausahaan dan mengembangkannya, menghilangkan resiko yang terdapat dalam teknik analisis, mengembangkan empati dan dukungan bagi aspek unik dalam kewirausahaan, merubah sikap dan pemikiran yang salah terhadap perubahan, mendorong munculnya usaha baru, dan menstimulas elemen sosialisasi afektif.

Penelitian lain mengungkapkan selain pembelajaran kewirausahaan, motivasi berwirausaha menjadi faktor dalam peningkatan niat berwirausaha (Irawan \& Mulyadi, 2016). Pada dasarnya motivasi merupakan suatu dorongan baik dalam diri seseorang maupun dari luar atau dari lingkungan yang dapat mempengaruhi perilaku seseorang dalam melaksanakan aktivitasnya, dan apabila dikaitkan dengan pekerjaan yang dilaksanakan oleh seseorang maka tujuan dari pemberian motivasi dalam pembelajaran tersebut agar siswa lebih efektif dan efesien (Mulyadi, 2010). Motivasi pada manusia merupakan unsur yang sangat penting karena sebagai pendorong untuk melakukan sesuatu (Mulyadi \& Marlina, 2010).

Berdasarkan latar belakang masalah diatas, maka penulis merumuskan beberapa rumusan penelitian yaitu bagaimana pengaruh pembelajaran kewirausahaan terhadap niat berwirausaha siswa di SMK Negeri kota Bandung, bagaimana pengaruh motivasi terhadap niat berwirausaha siswa di SMK Negeri kota Bandung, dan pengaruh pembelajaran kewirausahaan dan motivasi berwirausaha terhadap niat berwirausaha siswa di SMK Negeri kota Bandung. Tujuan dari penelitian ini adalah untuk mengetahui pengaruh pembelajaran kewirausahaan terhadap niat berwirausaha siswa di SMK Negeri kota Bandung, pengaruh motivasi berwirausaha terhadap niat berwiruasaha siswa di SMK Negeri kota Bandung, dan pengaruh pembelajaran kewirausahaan dan motivasi berwirausaha terhadap niat berwirausahan siswa di SMK Negeri kota Bandung.

\section{METODE PENELITIAN}

Metode yang digunakan dalam penelitian ini adalah metode survey atau explanatory survey. Metode ini bertujuan untuk mengetahui pengaruh antar variabel dengan cara pengujian hipotesis. Unit analisis pada penelitian ini adalah siswa di SMK Negeri kota Bandung pada kurun waktu kurang dari satu tahun, sehingga teknik pengumpulan data yang digunakan pada penelitian ini adalah cross-sectional method. Cross sectional method pengumpulan informasi dari setiap elemen populasi sampel yang dilakukan hanya sekali pada waktu tertentu (Sumarwan 2011: 20).

Sampel dalam penelitian ini adalah 107 orang siswa di SMK Negeri kota Bandung dengan penarikan sampel menggunakan metode sampel Tabachnick \& Fidell (2013). Teknik pengumpulan data yang dilakukan dalam penelitian ini melalui penyebaran kuesioner. Teknik analisis data yang digunakan dalam penelitian ini adalah analisis verifikatif. Analisis verifikatif digunakan untuk melihat pengaruh lingkungan kerja dan kompensasi terhadap kepuasan kerja (Sugiyono, 2017: 147).

Variabel dalam penelitian terdiri dari pembelajaran kewirausahaan, motivasi berwirausaha, dan niat berwirausaha. Penelitian ini menggunakan pengukuran data berskala ordinal.

\section{HASIL DAN PEMBAHASAN}

Penelitian ini yang terdiri dari variabel bebas yaitu pemebalajaran kewiraushaan $\left(\mathrm{X}_{1}\right)$ dan motivasi berwirausaha $\left(\mathrm{X}_{2}\right)$ sedangkan untuk variabel terikatnya adalah niat berwirausaha (Y). Untuk mengetahui pengaruh pembelajaran kewirausahaan dan motivasi berwirausaha terhadap niat berwirausaha dilakukan pengujian regresi linier berganda. 
Model persamaan regresi berganda yang akan dibentuk pada penelitian ini sebagai berikut..

$$
\mathbf{Y}=\mathbf{a}+\mathbf{b}_{1} \mathbf{X}_{1}+\mathbf{b}_{2} \mathbf{X}_{2}+\mathbf{e}
$$

Sumber: Sugiyono $(2017 ; 192)$

Dimana :

$$
\begin{array}{ll}
\mathrm{Y} & =\text { Niat berwirausaha } \\
\mathrm{X}_{1} & =\text { Pembelajaran kewirausahaan } \\
\mathrm{X}_{2} & =\text { Motivasi berwirausaha } \\
\mathrm{a} & =\text { Bilangan konstanta } \\
\mathrm{b}_{1,2} & =\text { Koefisien regresi } \\
\mathrm{e} & =\text { Kesalahan pengganggu (standart error) }
\end{array}
$$

\begin{tabular}{|c|c|c|c|c|c|}
\hline \multirow[b]{3}{*}{ Model } & \multicolumn{5}{|c|}{ UnstandardizedStandardized } \\
\hline & \multicolumn{2}{|c|}{ Coefficients } & \multicolumn{2}{|c|}{ Coefficients } & \multirow[b]{2}{*}{ Sig. } \\
\hline & B & $\begin{array}{l}\text { Std. } \\
\text { Error }\end{array}$ & Beta & $\mathrm{t}$ & \\
\hline $1($ Constant $)$ & 3,890 & \multicolumn{2}{|l|}{1,501} & \multicolumn{2}{|c|}{$2,591,011$} \\
\hline Pembelajaran & \multirow{2}{*}{$n^{, 210}$} & \multirow[t]{2}{*}{037} & \multirow[t]{2}{*}{,499 } & \multicolumn{2}{|c|}{$5,633,000$} \\
\hline Kewirausahaan & & & & & \\
\hline Motivasi & \multirow[t]{2}{*}{,197 } & \multirow[t]{2}{*}{,045 } & \multirow[t]{2}{*}{,392 } & \multirow{2}{*}{\multicolumn{2}{|c|}{$4,421,000$}} \\
\hline Berwirausaha & & & & & \\
\hline
\end{tabular}

Berdasarkan hasil pengolahan data dengan bantuan program SPSS 24.0 for windows, diperoleh koefisien regresi linear berganda sebagai berikut.

Tabel 6. Koefisien korelasi model summary

Coefficients $^{\mathrm{a}}$

a. Dependent Variable: Niat Berwirausaha

Sumber: Hasil Pengolahan Data, 2019

Berdasarkan Tabel 6 pada kolom B, tercantum nilai konstanta dan nilai koefisien regresi linear berganda untuk variabel bebas. Berdasarkan nilainilai itu maka dapat ditentukan model regresi linear berganda yang dinyatakan dalam bentuk persamaan sebagai berikut:

$$
\begin{gathered}
\mathbf{Y}=\mathbf{a}+\mathbf{b}_{1} \mathbf{X}_{\mathbf{1}}+\mathbf{b}_{2} \mathbf{X}_{\mathbf{2}}+\mathbf{e} \\
\mathrm{Y}=3,890+0,210 \mathrm{X}_{1}+0,197 \mathrm{X}_{2}
\end{gathered}
$$

Persamaan diatas dapat diartikan sebagai berikut:

$\mathrm{a}=3,890$ : artinya jika variabel pembelajaran kewirausahaan $\left(\mathrm{X}_{1}\right)$, motivasi berwirausaha $\left(\mathrm{X}_{2}\right)$, bernilai nol $(0)$, maka niat berwirausaha (Y) akan bernilai 3,890 satuan.

$\mathrm{b}_{1}=0,210$ : artinya jika pembelajaran kewirausahaan $\left(\mathrm{X}_{1}\right)$ meningkat sebesar satu satuan dan variabel lainnya konstan, maka niat berwirausaha (Y) akan meningkat sebesar 0,210 satuan.

$\mathrm{b}_{2}=0,197$ : artinya jika motivasi berwirausaha $\left(\mathrm{X}_{2}\right)$ meningkat sebesar satu satuan dan variabel lainnya konstan, maka niat berwirausaha (Y) akan meningkat sebesar 0,197 satuan.

Untuk mengetahui besarnya persentase pengaruh $\mathrm{X}_{1}$ dan $\mathrm{X}_{2}$ terhadap $\mathrm{Y}$, koefisien determinasi dapat diketahui dengan rumus yang dikemukakan Riduwan (2013: 136) yaitu :

\begin{tabular}{|c|c|c|c|}
\hline \multirow[b]{2}{*}{ Model } & $\mathrm{R}$ & Adjusted R & Std. Error of the \\
\hline & \multicolumn{2}{|c|}{ Square Square } & Estimate \\
\hline 1 & $, 816^{\mathrm{a}}, 666$ & ,663 & 4,584 \\
\hline \multicolumn{4}{|c|}{$\begin{array}{l}\text { a. Predictors: (Constant), Pembelajaran Kewi } \\
\text { b. Dependent Variable: Niat Berwirausaha } \\
\text { Sumber: Hasil Pengolahan Data, } 2019\end{array}$} \\
\hline $\begin{aligned} \mathrm{KD} & = \\
& =\end{aligned}$ & $\begin{array}{l}r^{2} \times 100 \% \\
(0,816)^{2} \times \\
66,6 \%\end{array}$ & $100 \%$ & \\
\hline
\end{tabular}

$$
K D=r^{2} \times 100 \%
$$

Keterangan :

$$
\begin{array}{ll}
\mathrm{KD} & =\text { Koefisien determinasi } \\
\mathrm{r} & =\text { Koefisien korelasi } \\
100 \% & =\text { Konstanta }
\end{array}
$$

Pengaruh pembelajaran kewirausahaan terhadap niat berwirausaha dapat dilihat dari hasil Tabel 7 berikut:

\section{Tabel 7. Koefisien Determinasi Secara Parsial}

Model Summary

Maka diperoleh nilai KD sebesar $66,6 \%$ yang menunjukkan arti bahwa pembelajaran kewirausahaan memberikan pengaruh secara parsial sebesar 66,6\% terhadap niat berwirausaha. Sedangkan sisanya sebesar $33,4 \%$ dipengaruhi oleh faktor yang tidak diteliti pada penelitian ini, seperti 1) kebutuhan akan prestasi, 2) kreatifitas, 3) kemandirian, 4) keberanian mengambil resiko, 5) toleransi keambiguan, dan 6) pengaruh orang tua (Vemmy, 2012).

Hasil tersebut sesuai dengan teori yang dikemukakan oleh Turker \& Selcuk (2008) yang menunjukkan bahwa pendidikan kewirausahaan dan dukungan struktural dalam bentuk kolaborasi dari semua sektor dalam masyarakat mempengaruhi seseorang untuk berwirausaha, 
selain itu menurut Chairy (2011) bahwa semakin tinggi kebutuhan akan prestasi maka semakin besar kemungkinan seorang individu berkeinginan untuk menjadi entrepreneur.

Pengaruh motivasi berwirausaha terhadap niat berwirausaha dapat dilihat dari hasil Tabel 8 berikut:

Tabel 8. Koefisien Determinasi Secara Parsial Model Summary ${ }^{\mathrm{b}}$

\begin{tabular}{|c|c|c|c|c|}
\hline & & $\mathrm{R}$ & Adjusted R & Std. Error of the \\
\hline Model & $\mathrm{R}$ & Square & Square & Estimate \\
\hline 1 & & a, 633 & ,630 & 4,805 \\
\hline
\end{tabular}

a. Predictors: (Constant), Motivasi Berwirausaha

b. Dependent Variable: Niat Berwirausaha

Sumber: Hasil Pengolahan Data, 2019

$\mathrm{KD} \quad=\mathrm{r}^{2} \times 100 \%$

$=(0,796)^{2} \times 100 \%$

$=63,0 \%$

Maka diperoleh nilai KD sebesar 63,3\% yang menunjukkan arti bahwa motivasi berwirausaha memberikan pengaruh secara parsial sebesar $63,3 \%$ terhadap niat berwirausaha. Sedangkan sisanya sebesar $36,7 \%$ dipengaruhi oleh faktor yang tidak diteliti pada penelitian ini, seperti 1) kebutuhan akan prestasi, 2) kreatifitas, 3) kemandirian, 4) keberanian mengambil resiko, 5) toleransi keambiguan, dan 6) pengaruh orang tua (Vemmy, 2012).

Hasil tersebut didukung oleh penelitian Riani et al., (2013) yang menyatakan dalam meningkatkan niat berwirausaha dapat melakukan pelatihan wirausaha, motivasi diri (khususnya business motivation training) dan juga menurut Sumanjaya et al., (2011) motivasi berwirausaha merupakan satu penggerak dari dalam diri mahasiswa sebagai rencana atau keinginan untuk menuju kesuksesan untuk berwirausaha.

Adapun pengaruh pembelajaran kewirausahaan dan motivasi berwirausaha terhadap niat berwirausaha dapat dilihat dari hasil Tabel 9 berikut:

Tabel 9. Koefisien Determinasi Secara Simultan Model Summary ${ }^{\mathrm{b}}$

\begin{tabular}{|c|c|c|c|}
\hline Model & $\begin{array}{l}\mathrm{R} \\
\text { Squar }\end{array}$ & $\begin{array}{l}\text { Adjusted R } \\
\text { Square }\end{array}$ & $\begin{array}{l}\text { Std. Error of the } \\
\text { Estimate }\end{array}$ \\
\hline 1 & $, 848^{\mathrm{a}}, 719$ & ,714 & 4,226 \\
\hline
\end{tabular}

a. Predictors: (Constant), Motivasi Berwirausaha, Pembelajaran Kewirausahaan

b. Dependent Variable: Niat Berwirausaha

Sumber: Hasil Pengolahan Data, 2019

$$
\begin{aligned}
\mathrm{KD} & =\mathrm{r}^{2} \times 100 \% \\
& =(0,848)^{2} \times 100 \% \\
& =71,9 \%
\end{aligned}
$$

Maka diperoleh nilai KD sebesar 71,9\% yang menunjukkan arti bahwa pembelajaran kewirausahaan dan motivasi berwirausaha memberikan pengaruh secara simultan sebesar 71,9\% terhadap niat berwirausaha. Sedangkan sisanya sebesar $28,1 \%$ dipengaruhi oleh faktor yang tidak diteliti pada penelitian ini, seperti 1) kebutuhan akan prestasi, 2) kreatifitas, 3) kemandirian, 4) keberanian mengambil resiko, 5) toleransi keambiguan, dan 6) pengaruh orang tua (Vemmy, 2012).

Hasil diatas didukung oleh teori yang dikemukakan oleh Farooq et al., (2016: 3146) bahwa niat pribadi dianggap sebagai elemen kunci utama dalam pengambilan keputusan pemilihan karir yang didasarkan karena adanya keinginan untuk menjadi bos sendiri dan kelayakan atas keuangan dari hasil usaha sehingga mampu membentuk perilaku individu sebagai seorang wirausaha (Ferreira, Fernandes, \& Ratten, 2017:22). Suryana (2009: 2) mengungkapkan motivasi menjadi wirausaha dapat melatar belakangi atau mendorong mahasiswa melakukan aktivitas dan memberi energi yang mengarah pada pencapaian kebutuhan, memberi kepuasan ataupun mengurangi ketidakseimbangan dengan membuka suatu usaha atau bisnis.

Uji statistik $\mathrm{t}$ pada dasarnya menunjukkan seberapa jauh pengaruh satu variabel penjelas/independen secara individual dalam menerangkan variabel dependen. Untuk mengetahui besarnya persentase pengaruh pembelajaran kewirausahaan dan motivasi berwirausaha terhadap niat berwirausaha. Maka menggunakan program SPSS 24.0 for windows, diperoleh output sebagai berikut:

Tabel 10. Nilai Signifikan Uji t

Coefficients $^{\mathrm{a}}$

\begin{tabular}{llll}
\hline & \multicolumn{3}{l}{ Unstandardized Standardized } \\
Model & Coefficients & Coefficients t & Sig. \\
\hline
\end{tabular}




\begin{tabular}{|c|c|c|c|c|}
\hline & B & $\begin{array}{l}\text { Std. } \\
\text { Error }\end{array}$ & Beta & \\
\hline 1(Constant) & 3,890 & 1,501 & & $2,591,011$ \\
\hline $\begin{array}{l}\text { Pembelajaran } \\
\text { Kewirausahaan }\end{array}$ &, 210 & ,037 & 499 & $5,633,000$ \\
\hline $\begin{array}{l}\text { Motivasi } \\
\text { Berwirausaha }\end{array}$ &, 197 & , 045 & ,392 & $4,421,000$ \\
\hline
\end{tabular}

a. Dependent Variable: Niat Berwirausaha

Sumber: Hasil Pengolahan Data, 2019

Tabel 10 menjelasakan perolehan thitung sebesar 5,633 untuk pembelajaran kewirausahaan dan 4,421 untuk motivasi berwirausaha. Tingkat signifikan $(\alpha)$ sebesar 5\%, dan derajat kebebasan df $=\mathrm{n}-\mathrm{k}=107-3=104$ didapat nilai ttabel 1,983.

Nilai $t_{\text {hitung }}$ pembelajaran kewirausahaan sebesar 5,633. Dikarenakan $t_{\text {hitung }}>t_{\text {tabel }}$ atau 5,633> 1,983, maka $\mathrm{H}_{\mathrm{a}}$ diterima artinya pembelajaran kewirausahaan berpengaruh signifikan terhadap niat berwirausaha, dengan besarnya pengaruh pembelajaran kewirausahaan terhadap niat berwirausaha sebesar 0,666 atau 66,6\% termasuk kedalam kategori kuat (Sugiyono, 2017: 184). Hasil tersebut sesuai dengan penelitian Fahdli, Ghina, Si, \& Putri (2017) yang menyatakan bahwa pembelajaran kewirausahaan berpengaruh secara signifikan terhadap niat berwirausaha. Penelitian yang dilakukan oleh Sumanjaya et al., (2011) menyatakan bahwa pembelajaran kewirausahaan berpengaruh secara signifikan terhadap niat berwirausaha.

Nilai thitung motivasi berwirausaha sebesar 4,421. Dikarenakan $t_{\text {hitung }}>t_{\text {tabel }}$ atau 4,421 $>1,983$ maka $\mathrm{H}_{\mathrm{a}}$ diterima, artinya motivasi berwirausaha berpengaruh signifikan terhadap niat berwirausaha, dengan besarnya pengaruh motivasi berwirausaha terhadap niat berwirausaha sebesar 0,633 atau 63,3\% termasuk kedalam kategori kuat (Sugiyono, 2017: 184). Hasil penelitian Rifkhan (2017) menyatakan bahwa motivasi berwirausah berpengaruh secara siginfikan terhadap niat berwirausaha, penelitian tersebut sesuai dengan hasil yang didapatkan oleh peneliti.

Uji statistik $F$ pada dasarnya menunjukkan apakah semua varibel independen atau bebas yang dimasukkan dalam model mempunyai pengaruh secara bersama-sama terhadap variabel dependen/terikat. Uji ini digunakan untuk menguji siginifikansi pengaruh pembelajaran kewirausahaan dan motivasi berwirausaha terhadap niat berwirausaha rumus uji $\mathrm{F}$ atau uji ANOVA dijelaskan pada tabel berikut.

\section{Tabel 11. Nilai Signifikan Uji F}

\begin{tabular}{llllll} 
ANOVA $^{\mathrm{a}}$ & \multicolumn{5}{c}{} \\
\hline & Sum of & \multicolumn{2}{c}{ Mean } \\
Model & Squares & df & Square & F & Sig. \\
\hline 1Regression & 4754,575 & 2 & 2377,287 & $133,102,000^{\mathrm{b}}$ \\
Residual & 1857,500 & 104 & 17,861 & & \\
Total & 6612,075 & 106 & & & \\
\hline
\end{tabular}

a. Dependent Variable: Niat Berwirausaha

b. Predictors: (Constant), Motivasi Berwirausaha,

Pembelajaran Kewirausahaan

Sumber: Hasil Pengolahan Data, 2019

Berdasarkan output pada tabel 11 diketahui nilai $\mathrm{F}_{\text {hitung }}$ sebesar 133,102 dengan p-value (sig) 0,000 . Dengan $\alpha=0,05$ serta derajat kebebasan df 2 $=\mathrm{n}-\mathrm{k}=107-3=104$ dan df $1=\mathrm{k}-1=3-1=2$, maka di dapat $F_{\text {tabel }}$ 3.08. Dikarenakan nilai $F_{\text {hitung }}>$ Ftabel $(133,102>3,08)$, maka $\mathrm{H}_{0}$ ditolak dan $\mathrm{H}_{\mathrm{a}}$ diterima, artinya pembelajaran kewirausahaan dan motivasi berwirausaha secara bersama-sama berpengaruh signifikan terhadap niat berwirausaha.

\section{KESIMPULAN}

Hasil penelitian menyatakan bahwa, pembelajaran kewirausahaan mempunyai pengaruh terhadap niat berwirausaha siswa dengan kategori kuat. Hal ini menunjukkan bahwa semakin efektif pembelajaran kewirausahaan di sekolah, maka semakin tinggi pula niat berwirausaha siswa di SMK Negeri kota Bandung. Motivasi berwirausaha berpengaruh terhadap niat berwirausaha siswa dengan kategori kuat, hal tersebut menunjukkan bahwa semakin tinggi motivasi berwirausaha yang dimiliki siswa, maka akan semakin tinggi pula niat berwirausaha siswa di SMK Negeri kota Bandung. Hasil lainnya adalah pembelajaran kewirausahaan dan motivasi berwirausaha berpengaruh terhadap niat berwirausaha siswa dengan kategori kuat. Hal tersebut menjelaskan bahwa semakin efektif pembelajaran kewirausahaan dan semakin tinggi motivasi berwirausaha siswa, maka akan semakin tinggi niat berwirausaha yang dimiliki oleh siswa di SMK Negeri kota Bandung.

Berdasarkan hasil penelitian, maka penulis menyarankan beberapa hal yang dapat 
meningkatkan nait berwirirausaha melalui pembelajaran. Peneliti menyarankan sekolah untuk menerapkan sistem evaluasi dengan metode evaluasi yang berbeda-beda, seperti menggunakan games, tanya jawab dan menggunakan media pembelajaran. Sedangkan untuk meningkatkan niat berwirausaha siswa melalui motivasi berwirausaha dapat dilakukan dengan cara Sekolah seharusnya dapat meciptakan self-effiaacy yang tinggi pada siswa agar terciptanya kemampuann dalam berwirausaha, seperti sering melakukan kegiatan praktek jual beli barang di depan kelas atau melakukan presentasi bisnis didepan kelas.

\section{DAFTAR PUSTAKA}

Alberti, F., Sciascia, S., \& Poli, A. (2004). Entrepreneurship Education : Notes on an Ongoing Debate. 14th Annual IntEnt Conference, 4-7.

Biraglia, A., \& Kadile, V. (2016). The Role of Entrepreneurial Passion and Creativity in Developing Entrepreneurial Intentions: Insights from American Homebrewers. Journal of Small Business Management, OO(00), 1-19. https://doi.org/10.1111/jsbm.12242

Breugst, N., Domurath, A., Patzelt, H., \& Klaukien, A. (2012). Perceptions of Entrepreneurial Passion and Employees' Commitment to Entrepreneurial Ventures. Entrepreneurship: Theory and Practice, 36(1), 171-192. https://doi.org/10.1111/j.15406520.2011.00491.x

Chairy. (2011). Pengaruh Karakteristik Entrepreneurial, Jenis Etnis, Jenis Kelamin Dan Profesi Orang Tua Terhadap Intensi Berwirausaha Mahasiswa. Jurnal Manajemen Dan Bisnis, 1(2), 245-259.

Davis, B. C., Webb, J. W., \& Coombs, J. E. (2014). Funder Decision-Making: the Role of Product Creativity, Entrepreneurial Passion, and Positive Affect ( Summary ). Frontiers of Entrepreneurship Research, 34(3), 3-4.

De Clercq, D., Honig, B., \& Martin, B. (2011). The Roles of Learning Orientation and Passion for Work in the Formation of Entrepreneurial Intention. International Small Business Journal, 31(6), 652676. https://doi.org/10.1177/0266242611432360

Fahdli, S. M., Ghina, A., Si, S., \& Putri, M. K. (2017). Pengaruh Pendidikan Kewirausahaan Terhadap Niat Berwirausaha Mahasiswa ( Studi kasus pada Mahasiswa MBTI Angkatan 2013 Telkom University ) The Effect of Entrepreneurship Education on Entrepreneurial Intention ( Case Study on MBTI Students batch 2013 ), 4(3), 24802487.
Farooq, M. S., Jaafar, N., Ayupp, K., Salam, M., Mughal, Y. H., Azam, F., \& Sajid, A. (2016). Impact of Entrepreneurial Skill and Family Occupation On Entrepreneurial Intentions. Journal of Entrepreneurship, 28(3), 3145-3148.

Ferreira, J. J., Fernandes, C. I., \& Ratten, V. (2017). The Influence of Entrepreneurship Education on Entrepreneurial Intentions. In Entrepreneurial Universities, Innovation, Technology, and Knowledge Management (pp. 19-34). https://doi.org/10.1007/978-3-319-47949-1

Irawan, A., \& Mulyadi, H. (2016). Pengaruh Keterampilan Wirausaha terhadap Keberhasilan Usaha. Journal of Business Management and Entrepreneurship Education, 1(1), 213-223.

Laaksonen, L., Ainamo, A., \& Karjalainen, T.-M. (2011). Entrepreneurial passion: an explorative case study of four metal music ventures. Journal of Research in Marketing and Entrepreneurship, 13(1), 18-36. https://doi.org/10.1108/14715201111147923

Lestari, R. B., \& Wijaya, T. (2012). Pengaruh Pendidikan Kewirausahaan terhadap Minat Berwirausaha Mahasiswa di STIE MDP, STMIK MDP, dan STIE MUSI. Jurnal Ilmiah STIE MDP, l(2), 112-119.

Mason-Jones D.R., R. and T. (1999). Article information: Int $J$ Logistics Management. https://doi.org/10.1108/09574090910954864

Mulyadi, H. (2010). Pengaruh Motivasi Dan Kompetensi Kerja Terhadap Produktivitas Kerja Karyawan Pada Pt. Galamedia Bandung Perkasa. Manajerial, 9(17), 97-111.

Mulyadi, H., \& Marlina, N. (2010). Kinerja Karyawan Pada Departemen Weaving. Strategic: Jurnal Pendidikan Manajemen Bisnis, 9.

Mulyadi, H., Razati, G., \& Ramadhanti, D. (2013). Pengaruh Status Sosial Ekonomi Orang Tua Terhadap Prestasi Belajar Siswa. Strategic: Jurnal Pendidikan Manajemen Bisnis, 3, 3-6.

Riani, A. L., Irianto, H., \& Widodo, A. (2013). Analisis Faktor Penentu Niat Berwirausaha Mahasiswa Universitas. KINERJA, 17(1), 45-56.

Riduwan. (2013). Cara Menggunakan dan Memakai Analisis Jalur (Path Analysis). Bandung: Alfabeta.

Rifkhan. (2017). Pengaruh Sikap, Dan Motivasi Terhadap Minat Berwirausaha Mahasiswa Akuntasi Universitas Pamulang. Jurnal Ilmiah Akuntansi Universitas Pamulang, 5(1), 121-154. Retrieved from http://openjournal.unpam.ac.id/index.php/JIA/artic le/view/645

Roy, R., Akhtar, F., \& Das, N. (2017). Entrepreneurial intention among science \&amp; technology students in India: extending the theory of planned behavior. International Entrepreneurship and 
Management

Journal.

https://doi.org/10.1007/s11365-017-0434-y

Sugiyono. (2017). Metode Penelitian Kuantitatif, Kualitatif dan $R \& D$. Bandung: Alfabeta.

Sukmaningrum, S., \& Rahardjo, M. (2017). FaktorFaktor yang Memepengaruhi Niat Berwirausaha Mahasiswa Menggunakan Theory of Planned Behavior. Diponegoro Journal of Management, 6(3), 1-12.

Sumanjaya, W., Widajanti, E., \& Lamidi. (2011). Pengaruh Karakteristik Kewirausahaan terhadap Niat Berwirausaha Pada Mahasiswa Fakultas Ekonomi UNISRI dengan Motivasi Berwirausaha sebagai Variabel Moderasi. Jurnal Ekonomi Dan Kewirausahaan, 16(4), 433-441.

Sumarwan, U. et al. (2011). Riset Pemasaran dan Konsumen: Panduan Riset dan Kajian Kepuasan, Perilaku, Pembelian, Gaya Hidup, Loyalitas dan Persepsi Risiko. Bogor: IPB Press.

Suryana. (2009). Kewirausahaan. Jakarta: Salemba Empat.

Tabachnick, \& Fidell. (2013). Using Multivariate Statisrics, Sixth Edition. Boston: Pearson Education, Inc.

Thahara, I. P., \& Mulyadi, H. (2016). Efektivitas Model Problem Based Learning Dalam Meningkatkan Kemampuan Berpikir Kritis Peserta Didik Pada Kelas Bisnis Dan Kewirausahaan. Jurnal of Business Management Education, 1(2), 70-74.

Thorgren, S., \& Wincent, J. (2015). Passion and habitual entrepreneurship. International Small Business Journal, 33(2), 216-227. https://doi.org/10.1177/0266242613487085

Turker, D., \& Selcuk, S. S. (2008). Which Factors Affect Entrepreneurial Intention of University Students? Journal of European Industrial Training, 33(2), 142-159.

Vemmy, C. (2012). Faktor-Faktor Yang Mempengaruhi Factors Affecting Entrepreneurial Intention of. Jurnal Pendidikan Vokasi, 2, 117-126. https://doi.org/10.1007/978-1-4419-0443-3 